\title{
Serum levels of soluble programmed death-ligand 1 (sPD-L1) in patients with primary central nervous system diffuse large B-cell lymphoma
}

Inju Cho ${ }^{1 \dagger}$, Hansang Lee ${ }^{2 \dagger}$, Sang Eun Yoon ${ }^{3}$, Kyung Ju Ryu ${ }^{4}$, Young Hyeh Ko ${ }^{5}$, Won Seog Kim ${ }^{3,4}$ and Seok Jin $\mathrm{Kim}^{3,4^{*}}$ (iD

\begin{abstract}
Background: The interaction of programmed death-1 protein (PD-1) and programmed death-1 ligand (PD-L1) produces immunosuppressive activity, protecting tumor cells from anti-tumor immunity and possibly releasing soluble PD-L1 (sPD-L1) from PD-L1 expressing tumor cells. Therefore, we measured serum levels of sPD-L1 in patients with primary central nervous system lymphoma (PCNSL) and explored its clinical implications.
\end{abstract}

Methods: Sixty-eight patients with newly diagnosed PCNSL had diffuse large B-cell lymphoma and were treated with high-dose methotrexate-containing chemotherapy. The measurement of SPD-L1 and cytokines was performed using serum samples archived at diagnosis, and the tissue expression of PD-L1 was also analyzed from archived paraffin-embedded tissue blocks. Disease relapse, progression-free survival (PFS), and overall survival (OS) were analyzed according to the extent of SPD-L1 in serum and PD-L1 in tissue.

Results: The median level of serum SPD-L1 $(0.429 \mathrm{ng} / \mathrm{mL})$ was higher than in healthy control patients $(0.364 \mathrm{ng} / \mathrm{mL})$. The occurrence of relapse was more frequent in the high SPD-L1 (78\%) than the low SPD-L1 group (50\%), though the groups did not have different clinical or pathological characteristics at diagnosis. As a result, the OS and PFS for the high SPD-L1 group were significantly lower than those in the low group. PD-L1-positive tumor cells were found in 35 patients (67\%), and the extent of PD-L1-postive tumor cells was positively associated with serum SPD-L1 levels $(r=0.299, P=0.031)$. Among the 34 cytokines analyzed, only the serum level of IL-7 correlated with the serum level of SPD-L1 ( $r=0.521, P<0.001)$.

Conclusions: Serum levels of SPD-L1 could reflect the expression of PD-L1 in PCNSL tumor cells and predict patient survival outcomes. Therefore, SPD-L1 in serum could be a feasible biomarker for determining a risk-adapted treatment strategy for PCNSL patients.

(Continued on next page)

\footnotetext{
* Correspondence: kstwoh@skku.edu

${ }^{\dagger}$ Inju Cho and Hansang Lee contributed equally as co-first authors.

${ }^{3}$ Division of Hematology and Oncology, Department of Medicine, Samsung

Medical Center, Sungkyunkwan University School of Medicine, 81 Irwon-ro,

Gangnam-gu, Seoul 06351, South Korea

${ }^{4}$ Department of Health Sciences and Technology, Samsung Advanced

Institute for Health Sciences and Technology, Sungkyunkwan University,

Seoul, South Korea

Full list of author information is available at the end of the article
}

(c) The Author(s). 2020 Open Access This article is distributed under the terms of the Creative Commons Attribution 4.0 International License (http://creativecommons.org/licenses/by/4.0/), which permits unrestricted use, distribution, and reproduction in any medium, provided you give appropriate credit to the original author(s) and the source, provide a link to the Creative Commons license, and indicate if changes were made. The Creative Commons Public Domain Dedication waiver (http://creativecommons.org/publicdomain/zero/1.0/) applies to the data made available in this article, unless otherwise stated. 
(Continued from previous page)

Trial registration: The study population was patients who were diagnosed with PCNSL between January 2009 and February 2017 and registered for our prospective cohort studies after providing written informed consent (ClinicalTrials.gov: NCT00822731 [date of registration - January 14, 2009] and NCT01877109 [date of registration June 13, 2013]).

Keywords: Soluble PD-L1, PD-1, Primary central nervous system lymphoma,

\section{Background}

Primary central nervous system lymphoma (PCNSL) is a rare but aggressive non-Hodgkin lymphoma (NHL) that is confined to the brain, spinal cord, leptomeninges, and eyes [1]. Most cases of PCNSL have diffuse large B-cell lymphoma (DLBCL) histopathology, but PCNSL accounts for less than $3 \%$ of all primary tumors of the CNS and 1 to $2 \%$ of all NHLs [2-4]. Currently, highdose methotrexate (HD-MTX) is the backbone of the multi-agent chemotherapies used, and HD-MTXcontaining chemotherapy with or without whole brain radiotherapy (WBRT) has produced response rates of 70 to $90 \%$ in patients newly diagnosed with PCNSL [5-9]. However, almost $50 \%$ of patients relapse within the first two years after diagnosis, and one-third become refractory to conventional chemotherapy [10-12]. Salvage treatment options for relapsed/refractory PCNSL include high-dose chemotherapy followed by autologous stem cell transplantation (ASCT) or WBRT [13-15]. However, responses to those treatments are usually not durable, and ASCT cannot be used for frail elderly patients. Given the high probability of treatment failure and limited treatment options for frail elderly patients, the development of more effective salvage treatment with less toxicity has been an unmet need for PCNSL.

PD-1 is an inhibitory receptor expressed on activated $\mathrm{T}$ cells, and its interaction with PD-L1 suppresses T-cell mediated immune response allowing tumor cells to escape from anti-tumor immunity [16]. As immune checkpoint inhibitors blocking PD-1 have shown their efficacy in relapsed or refractory lymphoma patients, the role of PD1 inhibitor as a salvage treatment also has been emerging in patient with PCNSL. Indeed, nivolumab showed single-agent activity in relapsed and refractory PCNSL patients, and frequent copy-number alterations in $9 p 24.1 / P D-L 1 / P D-L 2$ of tumor cells leading to the expression of PD-L1 and PD-L2 were found in PCNSL [17, 18]. However, the assessment of PD-L1 and L2 in tumor tissue is not always possible in patients with PCNSL due to the risk of post-biopsy complications. The soluble programmed death-ligand 1 (sPD-L1) is secreted from PD-L1 positive cells, and can easily be measured using an enzyme-linked immunosorbent assay (ELISA) [19]. Thus, the measurement of sPD-L1 might become an indirect marker reflecting the expression of PD-L1 in tumor tissue. Indeed, elevated levels of sPD-L1 were reported to affect overall survival in DLBCL patients in a previous French multi-center trial [20]. In this study, we measured the level of sPD-L1 in patients with PCNSL and analyzed its clinical relevance as a prognostic marker, as well as its correlation with PD-L1 expression in tumor cells.

\section{Methods}

\section{Patients}

The study population was patients who were diagnosed with PCNSL between January 2009 and February 2017 and registered for our prospective cohort studies after providing written informed consent (NCT00822731 and NCT01877109). In our prospective cohort studies, we collected serum samples and the pre-treatment characteristics of patients at diagnosis. Treatment and outcome-related data, including treatment regimens, tumor response, date of progression, and date of death, were regularly updated. These cohort studies were approved by the Institutional Review Board of Samsung Medical Center, and all investigations were conducted according to the principles expressed in the Declaration of Helsinki and its contemporary amendments. Because patients with all subtypes of lymphoma were enrolled, the evaluations for work-up and treatments were performed according to our clinical practice for each subtype. For patients with PCNSL, the initial evaluation was done according to the International Primary CNS Lymphoma Collaborative Group recommendations [21]. Cerebrospinal fluid (CSF) analyses and ophthalmic examinations were also performed in most patients to test for leptomeningeal and ocular invasion. As the primary treatment for newly diagnosed PCNSL, HD-MTXcontaining chemotherapy with or without WBRT was used. Response was assessed according to the response criteria for PCNSL recommended by the International Primary CNS Lymphoma Collaborative Group [21]: complete response (CR) was defined as no contrast enhancement in brain magnetic resolution imaging (MRI) and negative findings in ocular and CSF examinations; partial response (PR) was defined as at least a $50 \%$ decrease in the enhancing tumor lesion; progressive disease (PD) was defined as at least a $25 \%$ increase in the lesion or any new lesion in the CNS or systemic sites; and 
stable disease (SD) was defined as less than a PR but not PD. Response evaluation was performed after the completion of primary treatment chemotherapy, and surveillance brain MRI was done to monitor the occurrence of disease relapse.

\section{Study design}

We retrospectively analyzed 68 patients who had archived serum samples available for measurement of sPD-L1 among patients enrolled in the aforementioned cohort studies, after excluding patients with secondary CNS involvement in systemic DLBCL. Using serum samples and ELISA, we first measured the SPD-L1 levels and correlated them with the clinical and pathological characteristics of the patients at diagnosis. Then, response to first-line therapy and the survival outcomes of patients were compared according to the level of sPD-L1. Second, we analyzed the expression of PD-L1 in tumor cells and non-tumor cells in 52 patients whose paraffinembedded tissue blocks were available for immunohistochemistry analyses. Third, we measured serum cytokines using multiplex ELISA to explore additional biomarkers that might predict the outcomes of PCNSL patients and influence the level of sPD-L1 or the tissue expression of PD-L1. To confirm the DLBCL histology of our patients with PCNSL, two pathologists (I.C and Y.K) reviewed patients' histopathology slides using the 2017 World Health Organization classification [3]. Relapsed disease was defined as disease recurrence in patients who had no evidence of disease after cessation of therapy, and PD was defined as SD or PD during the primary treatment. Multiple diseases were defined as more than one lesion found in a radiologic evaluation, and deep regions of the brain were defined as the basal ganglia, brainstem, periventricular regions, and cerebellum. We updated the survival status in March 2019 for the survival analysis, and this study was approved by the Institutional Review Board of Samsung Medical Center (IRB No. 2019-05054).

\section{Measurement of serum SPD-L1}

Serum samples were collected at diagnosis and stored at $-80^{\circ} \mathrm{C}$ until analysis. Serum aliquots had not been previously thawed before use in our multiplex chemokine assay. The level of sPD-L1 was measured using ELISA kits (PDCD1LG1 ELISA kit, USCN Life Science, Wuhan, China) according to the manufacturers' instructions. Briefly, the microplate provided in the kit was precoated with an antibody specific to PDCD1LG1. Standards or samples were then added to the microplate wells with a biotin-conjugated antibody specific to PDCD1LG1. Next, avidin conjugated to horseradish peroxidase was added to each microplate well and incubated. After the enzyme-substrate reaction, the color change was measured spectrophotometrically at a wavelength of $450 \mathrm{~nm}$. To estimate the reference ranges of sPD-L1, we measured the levels of serum sPD-L1 in 12 normal individuals (6 males and 6 females, median age 51 (range 24-78). They voluntarily donated residual serum samples that were left after blood tests during their regular health check-up. The SPD-L1 values in the blood serum specimens of healthy controls were determined by the same method. The measurement of each sample was done in duplicate.

\section{Immunohistochemistry for tissue PD-L1 expression}

Immunohistochemistry was performed on paraffin tissue sections (4- $\mu \mathrm{m}$ thick), and the PD-L1 antibody (Spring Bioscience, CA, USA; clone SP142, M4421, rabbit antihuman PD-L1/CD274, monoclonal antibody, 1:25 dilution) was used to assess the expression of PD-L1. The antibody was incubated for $120 \mathrm{~min}$ at $37^{\circ} \mathrm{C}$ using the Ventana BenchMark XT platform after antigen retrieval for $92 \mathrm{~min}$ with $\mathrm{CC1}$ buffer. Signal visualization was done using the OptiView DAB immunohistochemistry detection kit (Ventana, Tucson, Azusa) and OptiView Amplification kit (Ventana, Tucson, Azusa). Tonsil squamous epithelium was used as a PD-L1 immunohistochemistry positive control [22]. The slides were semiquantitatively analyzed by two pathologists (I. C and Y. K). The extent of PD-L1 expression in tumor cells was defined as the proportion of tumor cells showing PD-L1 expression with any intensity in the tumor area [23]. Macrophages and lymphocytes infiltrating the tumor area were considered non-tumor immune cells, and the proportion of PD-L1 expression in them was assessed in the same manner as in the tumor cells. Tumor cells were discriminated from tumor infiltrating lymphocytes using morphology because the tumor cells had unequivocal morphologic characteristics that allowed discernment. The assessment of PD-L1 expression in tumor infiltrating macrophages was done by measuring PD-L1 expression in CD68-positively stained macrophages. PD-L1positive tumor cells were defined as those positively stained for PD-L1 with a distinct membranous, cytoplasmic, or punctate/granular pattern of any intensity based on previously published descriptions [23, 24]. The following additional antibodies were used to assess CD68 expression and identify the cell of origin: CD68 (Leica Biosystem, Newcastle, NCL-L-CD68, mouse monoclonal, 1:50 dilution), CD10 (Novocastra, Newcastle, NCL-LCD10-270, mouse monoclonal, 1:100 dilution), BCL6 (Novocastra, Newcastle, NCL-L-Bcl-6-564, mouse monoclonal, 1:80 dilution), and MUM1 (Dako, CA, M7259, mouse monoclonal, 1:100 dilution). To assess the positivity of Epstein-Barr virus (EBV) in tumor tissue, EBV-encoded RNA (EBER) in situ hybridization (ISH) was also performed because EBV-positivity could 
be associated with PD-L1 expression. EBER was detected using ISH and an EBV ISH kit (Leica Microsystems, Bannockburn, IL, USA). We used EBV-negative lymphoid tissues and the hybridization mixture without EBV oligonucleotides as negative controls.

\section{Multiplex cytokine assay}

We measured eotaxin-1, GRO $\alpha$, interferon (IFN)- $\alpha$, IFN$\gamma$, IL-1 $\alpha$, IL-1 $\beta$, IL-1RA, IL-2, IL-4, IL-5, IL-6, IL-7, IL-8, IL-9, IL-10, IL-12p70, IL-13, IL-15, IL-17 $\alpha$, IL-18, IL-21, IL-22, IL-23, IL-27, IL-31, interferon $\gamma$-induced protein (IP-10), monocyte chemoattractant protein 1 (MCP-1), macrophage inflammatory protein-1 $\alpha$ (MIP-1 $\alpha$ ), MIP$1 \beta$, regulated on activation $\mathrm{T}$ cell expressed and secreted (RANTES), stromal cell-derived factor $1 \alpha$ (SDF1 $\alpha)$, tumor necrosis factor (TNF)- $\alpha$, and TNF- $\beta$ levels in duplicate with a ProcartaPlex ${ }^{\text {TM }}$ multiplex immunoassay kit (Invitrogen, Camarillo, CA, USA) and the Bio-Plex Cytokine Assay System (Bio-Rad Laboratories, Hercules, CA, USA) according to the manufacturer's instructions.

\section{Statistical analysis}

In the survival analysis, overall survival (OS) was designated as the time from the date of diagnosis to the date of death or last follow-up and progression-free survival (PFS) was designated as the time from the date of diagnosis to the date of progression or relapse, death, or last follow-up. The optimal cutoff value for the survival analysis was determined using the receiver-operating characteristic (ROC) curve method. Kaplan-Meier survival graphs and log-rank tests were used for the univariate survival analyses, and Cox proportional regression models were used for the multivariate analyses. A bivariate analysis of sPD-L1 and tissue expression of PDL1 was done to analyze their correlation. The chi-square test or Fisher's exact test were used to analyze their associations with clinical and pathological characteristics. In all comparisons, $P$-values less than 0.05 were considered statistically significant, and all P-values correspond to two-tailed significance tests. Statistical analyses were carried out using SPSS software version 21.0 (IBM, Armonk, New York, USA).

\section{Results}

\section{Characteristics and treatment outcomes of patients}

The median age of the 68 patients was 55 years (range: $20-77$ years), and $40 \%$ of the patients were older than 60 years at diagnosis (Table 1). Female patients were predominant, and most patients had good performance status (Eastern Cooperative Oncology Group grade 0-1). There were no patients with known immunosuppression such as the history of post-organ transplantation state or human immunodeficiency virus infection or immunosuppressive medications. The majority of patients had
Table 1 Patient characteristics

\begin{tabular}{|c|c|c|c|c|c|c|c|}
\hline & \multicolumn{2}{|c|}{$\begin{array}{l}\text { All patients } \\
(n=68)\end{array}$} & \multicolumn{2}{|c|}{$\begin{array}{l}\text { Low sPD-L1 } \\
(n=36)\end{array}$} & \multicolumn{2}{|c|}{$\begin{array}{l}\text { High sPD-L1 } \\
(n=32)\end{array}$} & \multirow[b]{2}{*}{ P } \\
\hline & $n$ & $(\%)$ & $n$ & $(\%)$ & $n$ & (\%) & \\
\hline \multicolumn{8}{|l|}{ Age (years) } \\
\hline$\leq 60$ & 41 & $(60)$ & 22 & $(61)$ & 19 & (59) & \multirow[t]{2}{*}{0.884} \\
\hline$>60$ & 27 & $(40)$ & 14 & (39) & 13 & (41) & \\
\hline \multicolumn{8}{|l|}{ Sex } \\
\hline Male & 27 & $(40)$ & 13 & $(36)$ & 14 & (44) & \multirow[t]{2}{*}{0.622} \\
\hline Female & 41 & $(60)$ & 23 & $(64)$ & 18 & (56) & \\
\hline \multicolumn{8}{|l|}{ ECOG PS } \\
\hline $0-1$ & 56 & $(82)$ & 33 & $(92)$ & 23 & (72) & \multirow[t]{2}{*}{0.054} \\
\hline$\geq 2$ & 12 & (18) & 3 & (8) & 9 & (28) & \\
\hline \multicolumn{8}{|c|}{ Serum Lactate dehydrogenase } \\
\hline Normal & 54 & (79) & 29 & $(81)$ & 25 & (78) & \multirow[t]{2}{*}{$>0.999$} \\
\hline Elevated & 14 & $(21)$ & 7 & (19) & 7 & (22) & \\
\hline \multicolumn{8}{|l|}{ Number of lesions } \\
\hline Single & 11 & $(16)$ & 7 & (19) & 4 & (12) & \multirow[t]{2}{*}{0.521} \\
\hline Multiple & 57 & $(84)$ & 29 & $(81)$ & 28 & (88) & \\
\hline \multicolumn{8}{|c|}{ Brain deep region involvement } \\
\hline Absence & 44 & $(65)$ & 23 & $(64)$ & 21 & (66) & \multirow[t]{2}{*}{$>0.999$} \\
\hline Presence & 24 & (35) & 13 & $(36)$ & 11 & (34) & \\
\hline \multicolumn{8}{|c|}{ Cell of origin subtype } \\
\hline GCB & 13 & (19) & 8 & $(22)$ & 5 & (16) & \multirow[t]{3}{*}{0.719} \\
\hline$A B C$ & 50 & (74) & 25 & $(69)$ & 25 & (78) & \\
\hline Not evaluated & 5 & (7) & 3 & (8) & 2 & (6) & \\
\hline \multicolumn{8}{|l|}{ Ki67 } \\
\hline$<90$ & 23 & (34) & 11 & $(31)$ & 12 & (38) & \multirow[t]{2}{*}{0.769} \\
\hline$\geq 90$ & 42 & $(62)$ & 23 & $(64)$ & 19 & (59) & \\
\hline Not evaluated & 3 & (4) & 2 & (6) & 1 & (3) & \\
\hline
\end{tabular}

multiple lesions in the CNS, including 8 cases with combined leptomeningeal and parenchymal involvement, and twenty-seven patients (35\%) with a tumor in the deep region of the brain (Table 1). Histologically, the activated $\mathrm{B}$-cell $(\mathrm{ABC})$ type $(74 \%)$ was dominant over the germinal center type (19\%, Table 1). All patients received HD-MTX-containing chemotherapy as follows: MTX $3.5 \mathrm{~g} / \mathrm{m}^{2}$ on day 1 , vincristine $1.4 \mathrm{~g} / \mathrm{m}^{2}$ on day 1 , and procarbazine $100 \mathrm{mg} / \mathrm{m}^{2}$ on day $1-7$ every two weeks (total 5 cycles). Among the 68 patients, $90 \%$ completed the planned cycle of HD-MTX chemotherapy (5 cycles in 10 weeks); 7 patients failed to complete the planned treatment due to lack of response or intolerance to treatment (Table 2). Intrathecal chemotherapy and WBRT were performed as adjuvant treatments at the physicians' discretion. Although 97\% of patients responded to the primary treatment, disease relapse occurred in 57\% of patients, and ASCT was done in 12 
Table 2 Treatment and patient outcomes

\begin{tabular}{|c|c|c|c|c|c|c|c|}
\hline & \multicolumn{2}{|c|}{$\begin{array}{l}\text { All patients } \\
(n=68)\end{array}$} & \multicolumn{2}{|c|}{$\begin{array}{l}\text { Low sPD-L1 } \\
(n=36)\end{array}$} & \multicolumn{2}{|c|}{$\begin{array}{l}\text { High sPD-L1 } \\
(n=32)\end{array}$} & \multirow[b]{2}{*}{$P$} \\
\hline & $n$ & $(\%)$ & $n$ & $(\%)$ & $n$ & $(\%)$ & \\
\hline \multicolumn{8}{|l|}{ HD-MTX chemotherapy } \\
\hline Completed & 61 & $(90)$ & 32 & (89) & 29 & (91) & $>0.999$ \\
\hline Failed to complete & 7 & $(10)$ & 4 & $(11)$ & 3 & (9) & \\
\hline \multicolumn{8}{|c|}{ Response to HD-MTX treatment } \\
\hline $\mathrm{CR} / \mathrm{PR}$ & $54 / 12$ & $(97)$ & $30 / 6$ & $(100)$ & $24 / 6$ & (94) & 0.486 \\
\hline $\mathrm{SD} / \mathrm{PD}$ & $1 / 1$ & (3) & $0 / 0$ & $(0)$ & $1 / 1$ & (6) & \\
\hline \multicolumn{8}{|c|}{ Intrathecal chemotherapy } \\
\hline Combined & 26 & $(38)$ & 10 & $(28)$ & 16 & $(50)$ & 0.081 \\
\hline Not combined & 42 & $(62)$ & 26 & $(72)$ & 16 & $(50)$ & \\
\hline \multicolumn{8}{|c|}{ Whole brain radiotherapy } \\
\hline Done & 45 & $(66)$ & 24 & $(67)$ & 21 & (67) & $>0.999$ \\
\hline Not done & 23 & (34) & 12 & (33) & 11 & (34) & \\
\hline \multicolumn{8}{|c|}{ Relapse after primary treatment } \\
\hline No relapse & 29 & $(43)$ & 18 & $(50)$ & 11 & $(34)$ & 0.226 \\
\hline Relapse & 39 & $(57)$ & 18 & $(50)$ & 21 & $(66)$ & \\
\hline \multicolumn{8}{|c|}{ Autologous stem cell transplantation } \\
\hline Done & 12 & $(18)$ & 7 & $(19)$ & 5 & $(16)$ & 0.758 \\
\hline Not done & 56 & $(82)$ & 29 & $(81)$ & 27 & $(84)$ & \\
\hline \multicolumn{8}{|l|}{ Relapse or progression } \\
\hline None & 25 & $(37)$ & 18 & $(50)$ & 7 & $(22)$ & 0.023 \\
\hline Occurred & 43 & $(63)$ & 18 & $(50)$ & 25 & $(78)$ & \\
\hline \multicolumn{8}{|l|}{ Survival status } \\
\hline Alive & 39 & $(57)$ & 27 & $(75)$ & 12 & $(37)$ & 0.003 \\
\hline Dead & 29 & (43) & 9 & (25) & 20 & (63) & \\
\hline
\end{tabular}

patients after salvage therapy. At the time of analysis, 39 patients were alive, and 29 patients had died (Table 2).

\section{Serum level of soluble PD-L1}

The median level of patients' serum sPD-L1 $(n=68)$ was $0.429 \mathrm{ng} / \mathrm{mL}$ (range: $0.324-0.757 \mathrm{ng} / \mathrm{mL}$ ), which was significantly higher than in the healthy control group $(0.364 \mathrm{ng} / \mathrm{mL}$; range: $0.329-0.390 \mathrm{ng} / \mathrm{mL}, \quad P<0.01$, Fig. 1a). The distribution of serum sPD-L1 among the 68 patients followed the normal distribution (Fig. 1b). The optimal cutoff for predicting OS was $0.432 \mathrm{ng} / \mathrm{mL}$, and the area under the curve of SPD-L1 for OS was 0.739 (Fig. 1c). According to this cutoff value, we dichotomized patients into low and high groups $(<0.432 \mathrm{ng} / \mathrm{mL}$ versus $\geq 0.432 \mathrm{ng} / \mathrm{mL}$ ). The OS and PFS of the high group were significantly lower than those of the low group (Fig. 1d, e). When we compared the low and high group patients' pre-treatment characteristics at diagnosis, we found no significant differences between them (Table 1). In other words, unfavorable parameters such as multiple lesions, deep brain involvement, $\mathrm{ABC}$ type, and high Ki67 were not associated with the high sPD-L1 group. All patients received the same treatment: HDMTX combination chemotherapy. Furthermore, their initial response to that therapy did not differ between groups either. However, relapse and progression were more frequent in the high sPD-L1 group (78\%, 25/32) than in the low sPD-L1 $(50 \%, 18 / 36)$ group $(P=0.023$, Table 2). As a result, the number of deaths in the high group $(n=20)$ was significantly higher than in the low group $(n=9$, Table 2$)$.

\section{Tissue expression of PD-L1}

Out of 52 patients who were analyzed for tissue expression of PD-L1, positively stained tumor cells were found in 35 patients $(67 \%, 35 / 52)$, whereas 17 patients did not show the presence of PD-L1-positive tumor cells. Among the 35 patients with PD-L1-positive tumor cells, the median percentage was $0.7 \%$ and 20 patients $(57 \%)$ had less than $1 \%$ of positivity. The extent of PD-L1 expression in the first and second quartiles (Q1, Q2) of serum sPD-L1 was lower than that in the third and fourth quartiles $(\mathrm{Q} 3, \mathrm{Q} 4$; Fig. 2a). In other words, the distribution of PD-L1-postive tumor cells showed a modest association with serum levels of sPD-L1 ( $r=$ $0.299, P=0.031$, Fig. $2 \mathrm{~b})$. The median percentage of positively stained immune cells, including macrophages, was $2.7 \%$ (Q1: 1.2\%-Q3: 6.3\%); however, the percentage of PD-L1-postive immune cells did not correlate with serum sPD-L1 levels (Fig. 2c). When patients were dichotomized into high $(n=15)$ and low $(n=37)$ groups based on the percentage of PD-L1-positive tumor cells ( $<1 \%$ versus $\geq 1 \%$ ), the OS of high group did not differ significantly from that of low group $(P=0.130$, Fig. $2 \mathrm{e})$. The comparison of OS according to the percentage of PD-L1-positive immune cells ( $<3 \%$ versus $\geq 3 \%$ ), the OS did not differ, either (Fig. 2f). However, PD-L1 expression of tumor cells showed a better association with OS than that of immune cells although they were not statistically significant. In the EBV ISH using tumor tissue, the EBV-positivity was found in only one case that was positive for PD-L1. Thus, our results did not show a significant association between EBV-positivity and PD-L1 expression in patients with PCNSL.

\section{Serum cytokines and SPD-L1}

The serum levels of cytokines from 68 patients were measured to explore their association with survival outcomes and the serum level of SPD-L1. Of the 34 cytokines measured in this study, 15 cytokines (eotaxin-1, GRO $\alpha$, IFN- $\alpha$, IL-1 $\alpha$, IL-7, IL-10, IL-18, IL-23, IP-10, MCP-1, MIP-1 $\alpha$, MIP-1 $\beta$, RANTES, SDF1 $\alpha$, and TNF- $\alpha$ ) could be analyzed; the remaining cytokines were not detectable in the majority of cases. In the ROC analysis for OS with these 15 cytokines, none of them showed more 


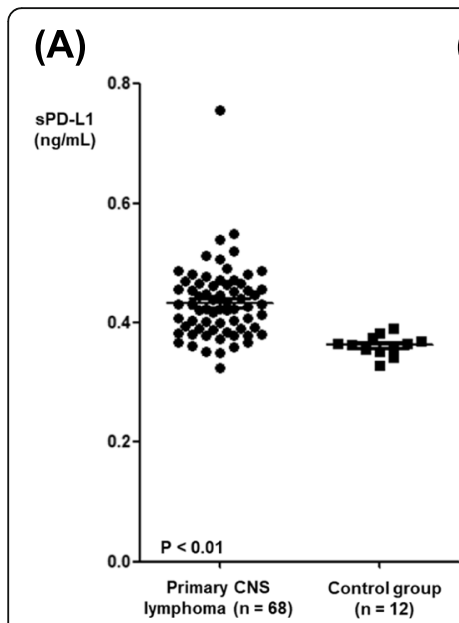

(D)

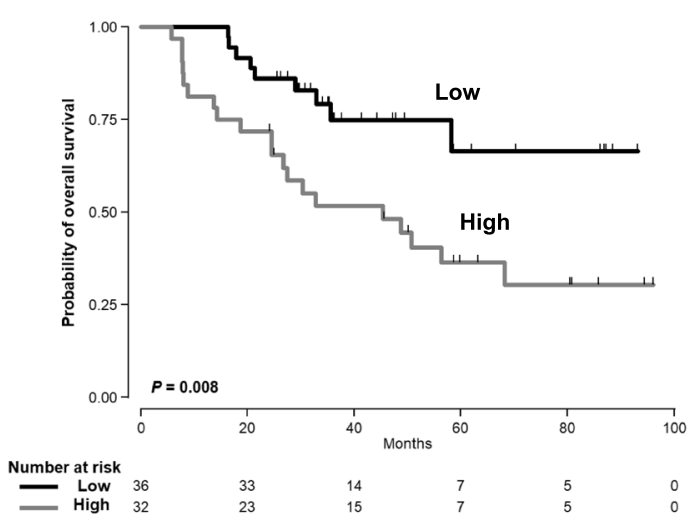

(B)

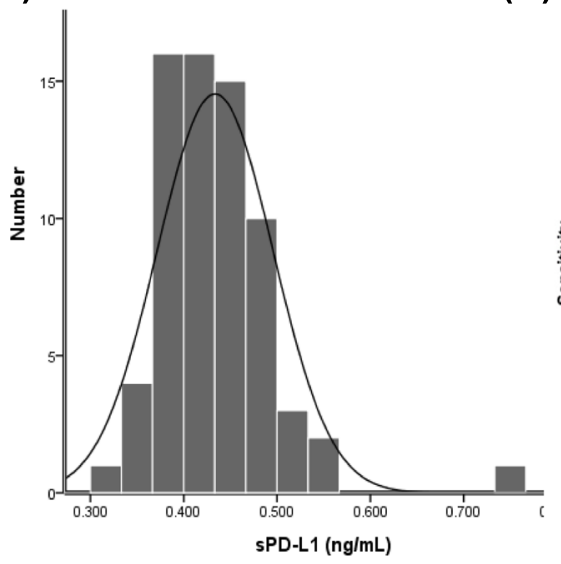

(C)

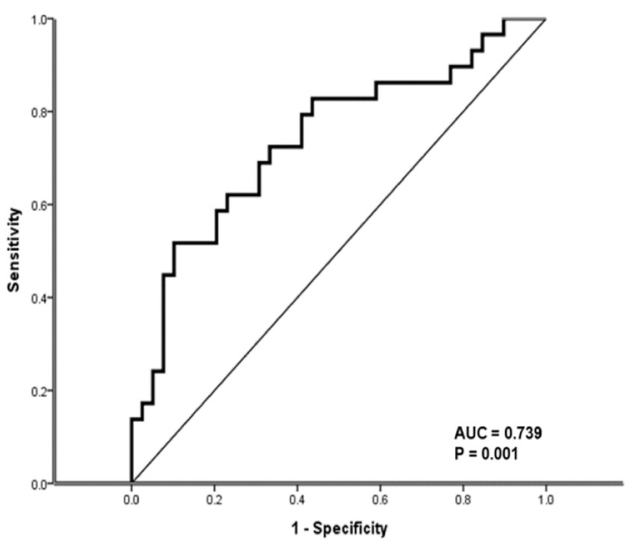

(E)

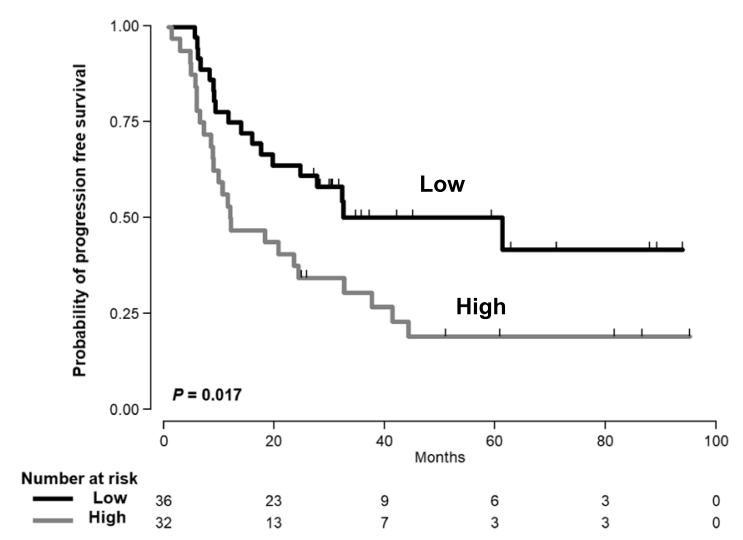

Fig. 1 a Comparison of serum SPD-L1 between patients with PCNSL $(n=68)$ and the healthy control group $(P<0.01)$. b The distribution of serum SPD-L1 in 68 patients. $\mathbf{c}$ The ROC curve of SPD-L1 for overall survival. d, e The overall survival and progression-free survival in the high sPD-L1 group were lower than those in the low SPD-L1 group

than 0.6 of area under the curve. Thus, an optimal cutoff for OS could not be obtained, and their levels were not associated with OS. However, the serum level of IL-7 did correlate with the serum level of sPD-L1 $(r=0.521$, $P<0.001$, Fig. 3a): the high sPD-L1 group had higher IL7 levels than the low sPD-L1 group (Fig. 3b). The comparison of OS based on the median value of Il-7 showed a trend of worse OS for patients in the high IL-7 group compared with those in the low IL-7 group, but that trend was not statistically significant (Fig. 3c).

\section{Discussion}

Since an association between sPD-L1 and prognosis was demonstrated in patients with renal cell carcinoma, the prognostic implications of sPD-L1 have been suggested in several solid cancers and hematologic malignancies [25-29]. A meta-analysis evaluating eight studies and 1102 patients with cancers of the lung, stomach, liver, and biliary tract; lymphoma; and myeloma indicated that a higher level of SPD-L1 was associated with worse OS
$(\mathrm{HR}=1.60$, 95\% CI: 1.21-1.99) [30]. However, the clinical relevance of sPD-L1 in patients with PCNSL has never been reported. In this study, we measured sPD-L1 from the archived serum samples of patients with PCNSL, and the median level in those patients $(0.429$ $\mathrm{ng} / \mathrm{mL}$, range: $0.324-0.757 \mathrm{ng} / \mathrm{mL}$ ) was lower than the previously reported values in other hematologic malignancies such as DLBCL (1.84 ng/mL), extranodal NK/Tcell lymphoma $(2.76 \mathrm{ng} / \mathrm{mL})$, and multiple myeloma $(4.15 \mathrm{ng} / \mathrm{mL}) \quad[28,31]$. The low level of sPD-L1 in PCNSL might be associated with the peculiar characteristics of PCNSL: tumors confined to the CNS have relatively small volume, and the blood-brain barrier might influence the level of sPD-L1 circulating in blood. Nevertheless, the serum level of sPD-L1 was significantly higher in patients with PCNSL than in healthy controls, and it had prognostic value for survival outcomes. The comparison of clinical and pathological characteristics based on serum SPD-L1 levels showed no differences between the high and low sPD-L1 groups in deep region 


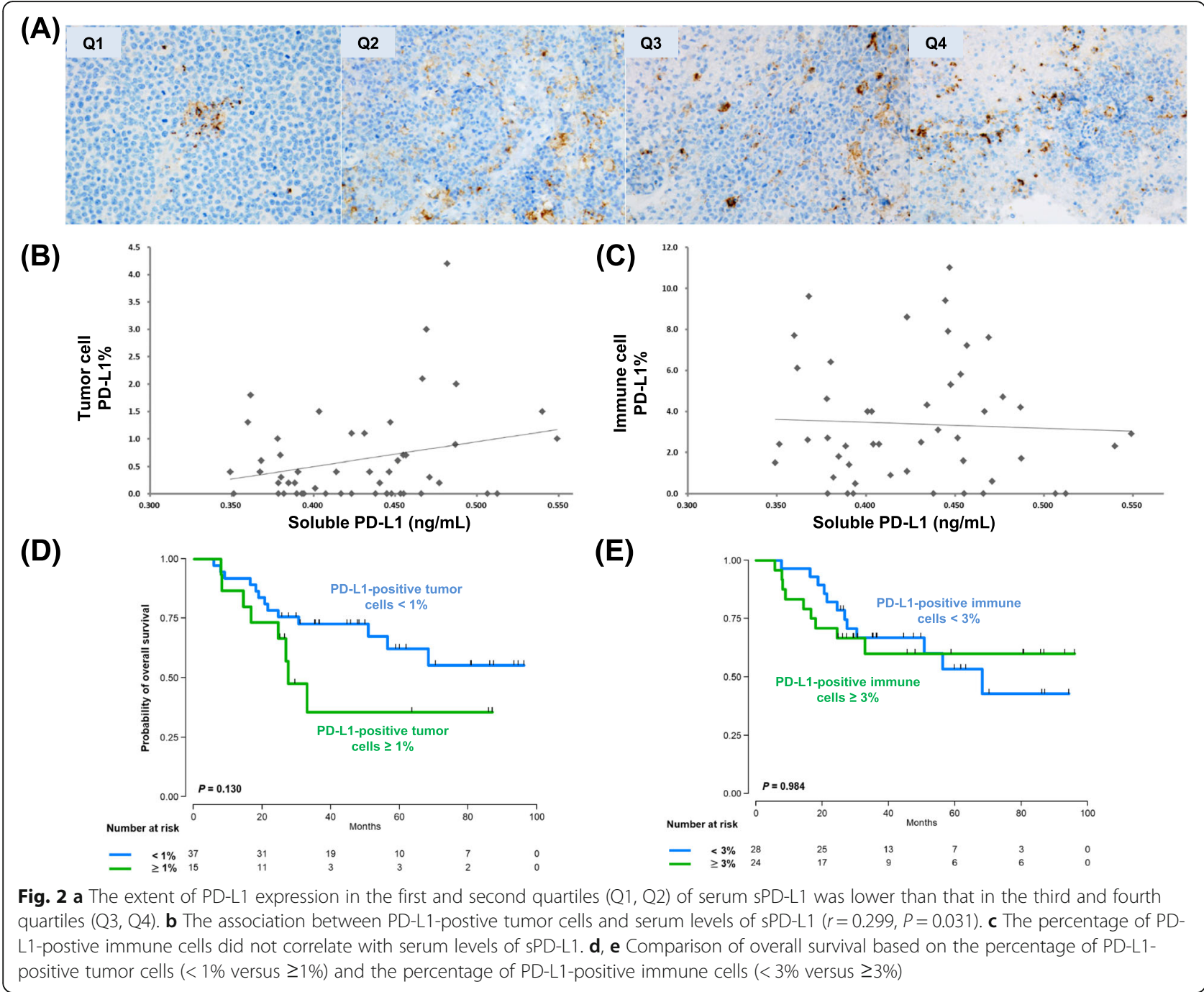

involvement, multiple lesions, cell of origin, or cell proliferation. Furthermore, even though most patients responded to the HD-MTX-containing chemotherapy, the high sPD-L1 group showed more frequent relapse or progression $(78 \%, 25 / 32)$, resulting in more deaths $(63 \%$, 20/32, Table 2) compared with the low sPD-L1 group. These results are consistent with the relationship between poor prognosis and high expression of PD-L1 in tumor cells $[32,33]$. Because overexpression of PD-L1 in tumor cells is related to the downregulation of effector $\mathrm{T}$-cell function and represents a potent mechanism of tumor immune evasion [34], our findings imply a possible role for sPD-L1 in allowing tumor cells to escape from anti-tumor immunity, similar to the T-cell exhaustion through the immune checkpoint mechanism seen in the PD1/PD-L1 axis $[35,36]$. Thus, patients with elevated levels of sPD-L1 might be more likely to have surviving residual tumor cells after HD-MTX-containing chemotherapy. Accordingly, the serum level of sPD-L1 could act as a reliable biomarker to predict the probability of relapse and survival outcome of patients with PCNSL.

Because circulating sPD-L1 could be secreted by PDL1-positive cells, we analyzed the association between serum levels of sPD-L1 and the percentage of PD-L1positive tumor cells. The distribution of PD-L1-postive tumor cells showed a modest association with serum levels of sPD-L1 $(r=0.299, P=0.031$, Fig. $2 b)$ whereas the percentage of PD-L1-postive immune cells including macrophages did not correlate with serum sPD-L1 levels (Fig. 2c). In line with those findings, the survival analysis showed a trend of better OS in patients with low PD-L1 expression compared to high PD-L1 $(P=0.130$, Fig. 2e), and the extent of PD-L1 expression in immune cells showed no difference between low and high groups $(P=$ 0.984, Fig. 2f). However, these results were not statistically significant. Although there might be various causes for this discrepancy between PD-L1 expression in tumor 

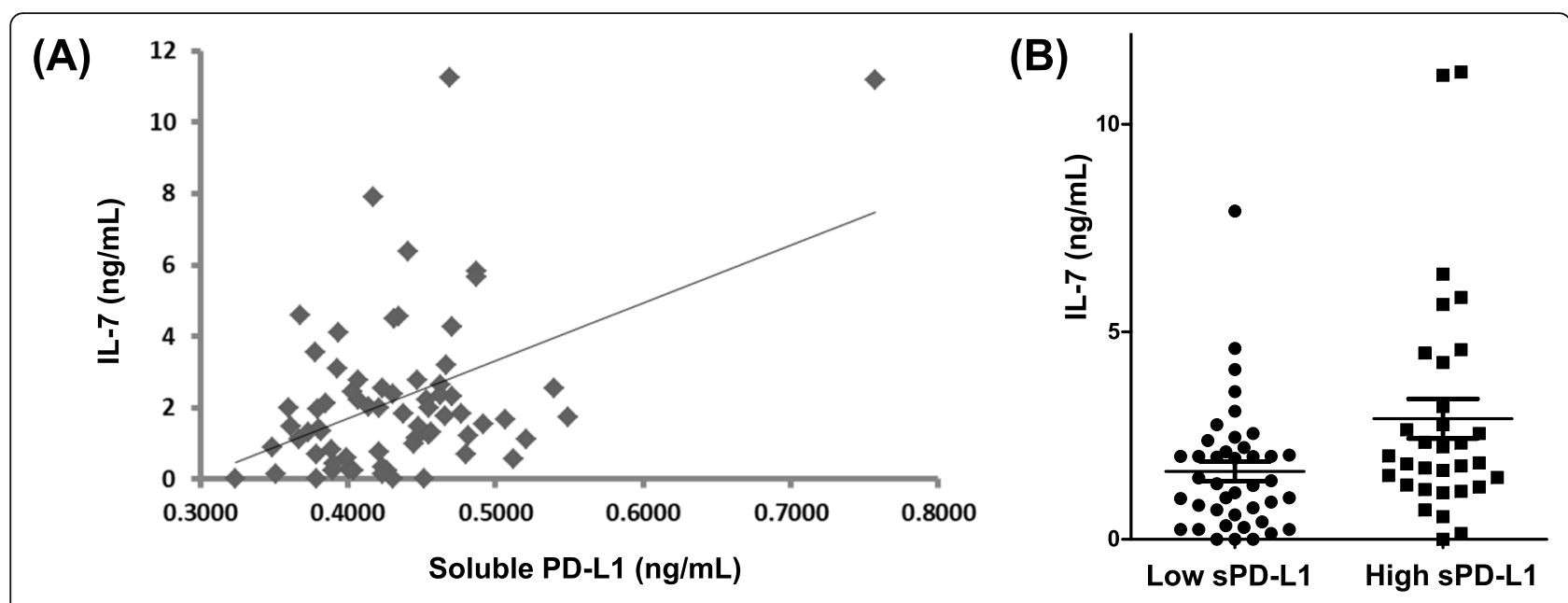

(C)

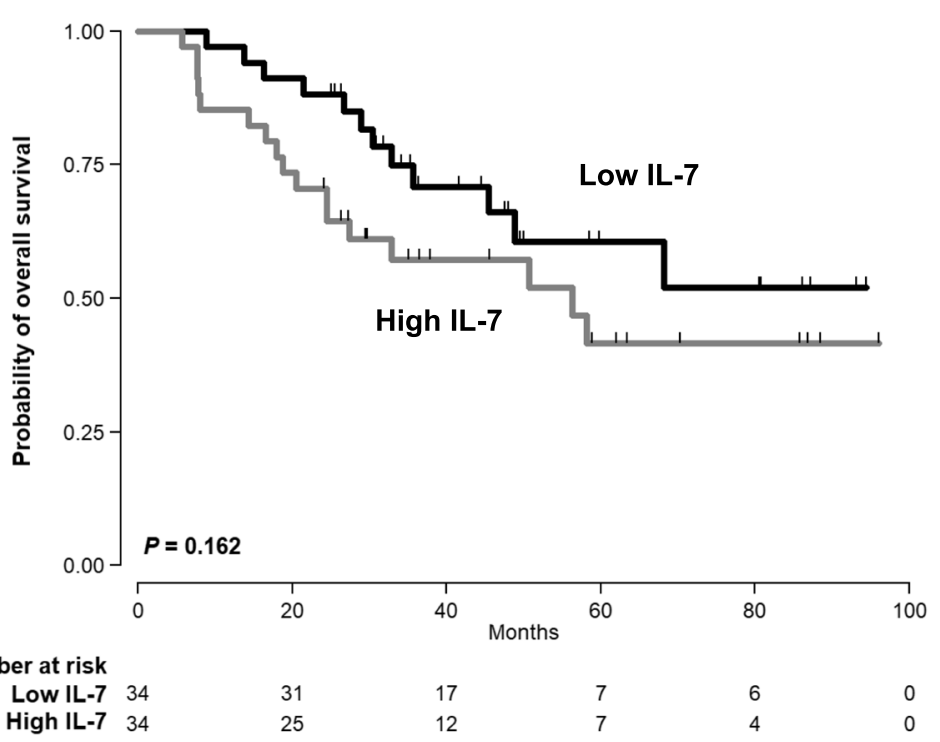

Fig. 3 a The association between serum IL-7 levels and serum SPD-L1 levels $(r=0.521, P<0.001)$. b The high sPD-L1 group showed a higher level of IL-7 than the low SPD-L1 group. c Comparison of overall survival based on the median value of II-7 showed a trend of worse OS for patients in the high IL-7 group compared with those in the low IL- group

tissue and sPD-L1 level in serum, the absence of an optimal cutoff for PD-L1 expression in PCNSL might have influenced our results. To date, no optimal cutoffs have been established, and various cutoffs for PD-L1 have been used in PCNSL patients (Table 3). This might be associated with differences in PD-L1 antibody clones, immunohistochemistry protocols, and the scoring systems used. Considering the discrepancy of serum SPDL1 with tumor tissue PD-L1 in terms of the association with survival, further study with larger study population should be performed to evaluate whether the measurement of SPD-L1 in serum could be a feasible and reproducible test for predicting the prognosis of PCNSL as well as the status of tissue PD-L1 expression. In addition, our results were from the single-center prospective cohort analyzing relatively small number of patients although PCNSL is a rare disease entity. Thus, our findings should be validated in an independent cohort study in the future.

In this study, we also analyzed the association between cytokine profiles and survival outcomes and serum SPDL1 levels in patients with PCNSL. Cytokines in the tumor microenvironment contribute to the growth and survival of tumor cells, and we previously demonstrated an association between inflammatory cytokines and the outcomes of lymphoma patients [42-44]. However, the 34 cytokines evaluated in our study failed to show a significant association with the survival outcomes of PCNSL patients. On the other hand, serum levels of sPD-L1 were significantly related to serum IL-7, which is 
Table 3 Summary of studies evaluating PD-L1 expression in primary CNS lymphoma

\begin{tabular}{|c|c|c|c|c|c|}
\hline & $\begin{array}{l}\text { Type of } \\
\text { specimen }\end{array}$ & PD-L1 clone & $\begin{array}{l}\text { Cut-off for PD-L1 } \\
\text { expression }\end{array}$ & Staining pattern & $\begin{array}{l}\text { Frequency of PD-L1 } \\
\text { expression }\end{array}$ \\
\hline $\begin{array}{l}\text { Berghoff et al } \\
\text { [37]. }\end{array}$ & Whole slide & Clone 5H1 (Abcam) & $\geq 5 \%$ of tumor cells & Membranous & $2 / 20(10 \%)$ \\
\hline Four et al [38]. & $\begin{array}{l}\text { Tissue } \\
\text { microarray }\end{array}$ & Clone SP142 (Ventana) & $\geq 1 \%$ of tumor cells & $\begin{array}{l}\text { Membranous and } \\
\text { cytoplasmic }\end{array}$ & $12 / 32(37.5 \%)$ \\
\hline $\begin{array}{l}\text { Hayano et al } \\
\text { [39]. }\end{array}$ & NA & $\begin{array}{l}\text { Clone E1L3N (Cell Signaling } \\
\text { Technology) }\end{array}$ & NA & Membranous & $2 / 64(4.1 \%)$ \\
\hline Cho et al [40]. & Tissue slide & Clone ab58810 (Abcam) & $\begin{array}{l}\geq 100 \text { cells/HPF of } \\
\text { tumor cells }\end{array}$ & NA & 10/76 (13.2\%) \\
\hline $\begin{array}{l}\text { Y Sugita et al } \\
{[41] \text {. }}\end{array}$ & Tissue slide & Clone EPR1161 (Abcam) & $\begin{array}{l}\text { no staining }(-) \text {; } \\
0-30 \%(1+) ; \\
30-60 \%(2+) \text {; } \\
>60 \%(3+) \\
\text { in both tumor cells and } \\
\text { TAM }\end{array}$ & Membranous & $\begin{array}{l}\text { 12/17 (70.6\%) in EBV- } \\
\text { positive cases. } \\
11 / 22(50 \%) \text { in EBV-negative } \\
\text { cases. }\end{array}$ \\
\hline
\end{tabular}

TAM tumor associated macrophages, HPF high power field, NA not available, EBV Epstein-Barr virus

mainly produced by non-lymphoid cells regulating $\mathrm{T}$ cell receptor $\gamma$ rearrangement [45]. Our results were consistent with a previous study reporting that $\gamma$-chain cytokines such as IL-2, IL-7, IL-15, and IL-21 could induce PD1 and PD-L1 expression [46]. Thus, although IL-7 failed to show a significant association with survival outcomes in PCNSL, it might increase the serum levels of sPD-L1 by increasing the tissue expression of PD-L1.

\section{Conclusions}

In conclusion, our study demonstrated that serum levels of sPD-L1 could reflect the expression of PD-L1 in PCNSL tumor cells and predict the survival outcomes of patients. Thus, sPD-L1 in serum could be a feasible biomarker for determining risk-adapted treatment strategies for PCNSL patients, including the use of PD-1 inhibitors. Further study with an independent cohort should be performed to validate our results in the future.

\section{Abbreviations}

BBB: Blood-brain barrier; HD-MTX: High-dose methotrexate; IFN: Interferon; IP10: Interferon $\mathrm{y}$-induced protein; MCP-1: Monocyte chemoattractant protein 1; MIP-1a: Macrophage inflammatory protein-1a; PCNSL: Primary central nervous system lymphoma; PD-1: Programmed death-1; PD-L1: Programmed death-1 ligand; RANTES: Regulated on activation T cell expressed and secreted; ROC: Receiver-operating characteristic; SDF1a: Stromal cell-derived factor 1a: TNF)-a: Tumor necrosis factor (TNF)-a; WBRT: Whole brain radiotherapy

\section{Acknowledgements}

We are grateful to all colleagues for participating in the research and express our gratitude to the 20-20 project of Samsung Medical Center and the National Research Foundation of Korea (NRF-2017R1A2B4005136).

\section{Authors' contributions}

SJK designed the study. IC, HL and SJK wrote the manuscript. WSK, SJK and SEY treated the patients, and collected the data. IC and YHK analyzed the pathology data. HL and KJR performed experiments and analyzed the data of serum cytokines. All authors read and approved the final manuscript.

\section{Funding}

This study was supported by a grant from the Basic Science Research Program through the National Research Foundation of Korea (NRF), which is funded by the Ministry of Education, Science, and Technology (NRF2017R1A2B4005136). The experiments of this study including immunohistochemistry and cytokine measurements were funded by the aforementioned grant. However, there was no role of the funding body in the design of the study and collection, analysis, and interpretation of data and in writing the manuscript.

\section{Availability of data and materials}

All data generated or analyzed during this study are available from the corresponding author on reasonable request.

\section{Ethics approval and consent to participate}

The study was approved by the Institutional Review Board of Samsung Medical Center (IRB No. 2019-05-054). Written informed consent was obtained from all eligible participants.

\section{Consent for publication}

Not applicable.

\section{Competing interests}

The authors declare that they have no competing interests.

\section{Author details}

'Department of Pathology, Yeouido St. Mary's Hospital, The Catholic University of Korea, Seoul, South Korea. ${ }^{2}$ Department of Internal Medicine, Dankook University College of Medicine, Cheonan, South Korea. ${ }^{3}$ Division of Hematology and Oncology, Department of Medicine, Samsung Medical Center, Sungkyunkwan University School of Medicine, 81 Irwon-ro, Gangnam-gu, Seoul 06351, South Korea. ${ }^{4}$ Department of Health Sciences and Technology, Samsung Advanced Institute for Health Sciences and Technology, Sungkyunkwan University, Seoul, South Korea. ${ }^{5}$ Department of Pathology and Translational Genomics, Samsung Medical Center, Sungkyunkwan University College of Medicine, Seoul, South Korea.

Received: 17 May 2019 Accepted: 7 February 2020

Published online: 13 February 2020

\section{References}

1. Gerstner ER, Batchelor TT. Primary central nervous system lymphoma. Arch Neurol. 2010;67(3):291-7.

2. Camilleri-Broet S, Martin A, Moreau A, Angonin R, Henin D, Gontier MF, Rousselet MC, Caulet-Maugendre S, Cuilliere P, Lefrancq T, et al. Primary central nervous system lymphomas in 72 immunocompetent patients: pathologic findings and clinical correlations. Groupe Ouest Est d'etude des 
Leucenies et Autres maladies du sang (GOELAMS). Am J Clin Pathol. 1998; 110(5):607-12.

3. Swerdlow S, Campo E, Harris N, et al. WHO Classification of Tumours of Haematopoietic and Lymphoid Tissues. In: WHO Classification of Tumours of Haematopoietic and Lymphoid Tissues. Revised 4th edn. Edited by Swerdlow S, Campo E, Harris N, et al. Lyon: IARC; 2017.

4. Grommes C, DeAngelis LM. Primary CNS Iymphoma. J Clin Oncol. 2017; 35(21):2410-8.

5. DeAngelis LM, Seiferheld W, Schold SC, Fisher B, Schultz CJ, Radiation therapy oncology group S. Combination chemotherapy and radiotherapy for primary central nervous system lymphoma: radiation therapy oncology group study 93-10. J Clin Oncol. 2002;20(24):4643-8.

6. Poortmans PM, Kluin-Nelemans HC, Haaxma-Reiche H, Van't Veer M, Hansen M, Soubeyran P, Taphoorn M, Thomas J, Van den Bent M, Fickers M, et al. High-dose methotrexate-based chemotherapy followed by consolidating radiotherapy in non-AIDS-related primary central nervous system lymphoma: European Organization for Research and Treatment of Cancer lymphoma group phase II trial 20962. J Clin Oncol. 2003;21(24):4483-8.

7. Ferreri AJ, Reni M, Foppoli M, Martelli M, Pangalis GA, Frezzato M, Cabras MG, Fabbri A, Corazzelli G, llariucci F, et al. High-dose cytarabine plus highdose methotrexate versus high-dose methotrexate alone in patients with primary CNS lymphoma: a randomised phase 2 trial. Lancet. 2009;374(9700): 1512-20.

8. Thiel E, Korfel A, Martus P, Kanz L, Griesinger F, Rauch M, Roth A, Hertenstein $B$, von Toll T, Hundsberger $T$, et al. High-dose methotrexate with or without whole brain radiotherapy for primary CNS lymphoma (GPCNSL-SG-1): a phase 3, randomised, non-inferiority trial. Lancet Oncol. 2010;11(11):1036-47.

9. Kim JE, Yoon DH, Kim S, Lee DH, Kim JH, Yoon YH, Chi HS, Lee SW, Park CS, Huh J, et al. Relapse pattern and prognostic factors for patients with primary central nervous system lymphoma. Korean J Hematol. 2012;47(1): 60-6.

10. Korfel A, Schlegel U. Diagnosis and treatment of primary CNS lymphoma. Nat Rev Neurol. 2013;9(6):317-27.

11. Hoang-Xuan K, Bessell E, Bromberg J, Hottinger AF, Preusser M, Ruda R, Schlegel U, Siegal T, Soussain C, Abacioglu U, et al. Diagnosis and treatment of primary CNS lymphoma in immunocompetent patients: guidelines from the European Association for Neuro-Oncology. Lancet Oncol. 2015;16(7): e322-32.

12. Langner-Lemercier $\mathrm{S}$, Houillier $\mathrm{C}$, Soussain $\mathrm{C}$, Ghesquieres $\mathrm{H}$, Chinot $\mathrm{O}$, Taillandier L, Soubeyran P, Lamy T, Morschhauser F, Benouaich-Amiel A, et al. Primary CNS lymphoma at first relapse/progression: characteristics, management, and outcome of 256 patients from the French LOC network. Neuro-oncology. 2016;18(9):1297-303.

13. Soussain C, Hoang-Xuan K, Taillandier L, Fourme E, Choquet S, Witz F, Casasnovas O, Dupriez B, Souleau B, Taksin AL, et al. Intensive chemotherapy followed by hematopoietic stem-cell rescue for refractory and recurrent primary CNS and intraocular lymphoma: Societe Francaise de Greffe de Moelle Osseuse-Therapie Cellulaire. J Clin Oncol. 2008;26(15): 2512-8

14. Choi MK, Kang ES, Kim DW, Ko YH, Seok H, Park JH, Pyo DH, Hoon Lim D, Kim SJ, Kim WS. Treatment outcome of relapsed/refractory primary central nervous system diffuse large B-cell lymphoma: a single-center experience of autologous stem cell transplantation. Int J Hematol. 2013;98(3):346-54.

15. Nguyen PL, Chakravarti A, Finkelstein DM, Hochberg FH, Batchelor TT, Loeffler JS. Results of whole-brain radiation as salvage of methotrexate failure for immunocompetent patients with primary CNS lymphoma. J Clin Oncol. 2005;23(7):1507-13.

16. Hude I, Sasse S, Engert A, Brockelmann PJ. The emerging role of immune checkpoint inhibition in malignant lymphoma. Haematologica. 2017;102(1): $30-42$.

17. Nayak L, Iwamoto FM, LaCasce A, Mukundan S, Roemer MGM, Chapuy B, Armand P, Rodig SJ, Shipp MA. PD-1 blockade with nivolumab in relapsed/ refractory primary central nervous system and testicular lymphoma. Blood. 2017;129(23):3071-3

18. Chapuy B, Roemer MG, Stewart C, Tan Y, Abo RP, Zhang L, Dunford AJ, Meredith DM, Thorner AR, Jordanova ES, et al. Targetable genetic features of primary testicular and primary central nervous system lymphomas. Blood. 2016;127(7):869-81.

19. Chen Y, Wang Q, Shi B, Xu P, Hu Z, Bai L, Zhang X. Development of a sandwich ELISA for evaluating soluble PD-L1 (CD274) in human sera of different ages as well as supernatants of PD-L1+ cell lines. Cytokine. 2011; 56(2):231-8.

20. Rossille D, Azzaoui I, Feldman AL, Maurer MJ, Laboure G, Parrens M, Pangault C, Habermann TM, Ansell SM, Link BK, et al. Soluble programmed death-ligand 1 as a prognostic biomarker for overall survival in patients with diffuse large B-cell lymphoma: a replication study and combined analysis of 508 patients. Leukemia. 2017;31(4):988-91.

21. Abrey LE, Batchelor TT, Ferreri AJ, Gospodarowicz M, Pulczynski EJ, Zucca E, Smith JR, Korfel A, Soussain C, DeAngelis LM, et al. Report of an international workshop to standardize baseline evaluation and response criteria for primary CNS lymphoma. J Clin Oncol. 2005;23(22):5034-43.

22. Phillips T, Simmons P, Inzunza HD, Cogswell J, Novotny J Jr, Taylor C, Zhang $X$. Development of an automated PD-L1 immunohistochemistry (IHC) assay for non-small cell lung cancer. Appl Immunohistochem Mol Morphol. 2015; 23(8):541-9.

23. Scheel AH, Dietel M, Heukamp LC, Johrens K, Kirchner T, Reu S, Ruschoff J, Schildhaus HU, Schirmacher P, Tiemann M, et al. Harmonized PD-L1 immunohistochemistry for pulmonary squamous-cell and adenocarcinomas. Mod Pathol. 2016:29(10):1165-72.

24. Menter T, Bodmer-Haecki A, Dirnhofer S, Tzankov A. Evaluation of the diagnostic and prognostic value of PDL1 expression in Hodgkin and B-cell lymphomas. Hum Pathol. 2016;54:17-24.

25. Frigola X, Inman BA, Lohse CM, Krco CJ, Cheville JC, Thompson RH, Leibovich B, Blute ML, Dong H, Kwon ED. Identification of a soluble form of $\mathrm{B} 7-\mathrm{H} 1$ that retains immunosuppressive activity and is associated with aggressive renal cell carcinoma. Clin Cancer Res. 2011;17(7):1915-23.

26. Wang $L$, Wang $H$, Chen $H$, Wang WD, Chen $X Q$, Geng QR, Xia ZJ, Lu Y. Serum levels of soluble programmed death ligand 1 predict treatment response and progression free survival in multiple myeloma. Oncotarget. 2015;6(38):41228-36.

27. Ha H, Nam AR, Bang JH, Park JE, Kim TY, Lee KH, Han SW, Im SA, Kim TY, Bang YJ, et al. Soluble programmed death-ligand 1 (sPDL1) and neutrophilto-lymphocyte ratio (NLR) predicts survival in advanced biliary tract cancer patients treated with palliative chemotherapy. Oncotarget. 2016;7(47): 76604-12.

28. Huang SY, Lin HH, Lin CW, Li CC, Yao M, Tang JL, Hou HA, Tsay W, Chou SJ, Cheng $\mathrm{CL}$, et al. Soluble PD-L1: a biomarker to predict progression of autologous transplantation in patients with multiple myeloma. Oncotarget. 2016;7(38):62490-502.

29. Okuma Y, Hosomi Y, Nakahara Y, Watanabe K, Sagawa Y, Homma S. High plasma levels of soluble programmed cell death ligand 1 are prognostic for reduced survival in advanced lung cancer. Lung Cancer. 2017;104:1-6.

30. Ding Y, Sun C, Li J, Hu L, Li M, Liu J, Pu L, Xiong S. The prognostic significance of soluble programmed death ligand 1 expression in cancers: a systematic review and meta-analysis. Scand J Immunol. 2017;86(5):361-7.

31. Wang $H$, Wang L, Liu WJ, Xia ZJ, Huang HQ, Jiang WQ, Li ZM, Lu Y. High post-treatment serum levels of soluble programmed cell death ligand 1 predict early relapse and poor prognosis in extranodal NK/T cell lymphoma patients. Oncotarget. 2016;7(22):33035-45.

32. Kiyasu J, Miyoshi H, Hirata A, Arakawa F, Ichikawa A, Niino D, Sugita Y, Yufu $Y$, Choi I, Abe Y, et al. Expression of programmed cell death ligand 1 is associated with poor overall survival in patients with diffuse large B-cell lymphoma. Blood. 2015;126(19):2193-201.

33. Juarez-Salcedo LM, Sandoval-Sus J, Sokol L, Chavez JC, Dalia S. The role of anti-PD-1 and anti-PD-L1 agents in the treatment of diffuse large B-cell lymphoma: the future is now. Crit Rev Oncol Hematol. 2017;113:52-62.

34. da Silva PB, Real JM, Ferreira LRP, Esteves GH, Brito FDN, Baiocchi OCG. Soluble PD-1 and PD-L1 as potential biomarkers for classical Hodgkin lymphoma. Hematol Oncol. 2018;36(4):709-12.

35. Zou W, Chen L. Inhibitory B7-family molecules in the tumour microenvironment. Nat Rev Immunol. 2008;8(6):467-77.

36. Lipson EJ, Vincent JG, Loyo M, Kagohara LT, Luber BS, Wang H, Xu H, Nayar SK, Wang TS, Sidransky D, et al. PD-L1 expression in the Merkel cell carcinoma microenvironment: association with inflammation, Merkel cell polyomavirus and overall survival. Cancer Immunol Res. 2013;1 (1):54-63.

37. Berghoff AS, Ricken G, Widhalm G, Rajky O, Hainfellner JA, Birner P, Raderer M, Preusser M. PD1 (CD279) and PD-L1 (CD274, B7H1) expression in primary central nervous system lymphomas (PCNSL). Clin Neuropathol. 2014;33(1):42-9.

38. Four M, Cacheux V, Tempier A, Platero D, Fabbro M, Marin G, Leventoux N, Rigau V, Costes-Martineau V, Szablewski V. PD1 and PDL1 expression in primary central nervous system diffuse large B-cell lymphoma are frequent 
and expression of PD1 predicts poor survival. Hematol Oncol. 2017;35(4): 487-96.

39. Hayano A, Komohara Y, Takashima Y, Takeya H, Homma J, Fukai J, Iwadate Y, Kajiwara K, Ishizawa S, Hondoh H, et al. Programmed cell death ligand 1 expression in primary central nervous system lymphomas: a Clinicopathological study. Anticancer Res. 2017;37(10):5655-66.

40. Cho H, Kim SH, Kim SJ, Chang JH, Yang WI, Suh CO, Kim YR, Jang JE, Cheong JW, Min YH, et al. Programmed cell death 1 expression is associated with inferior survival in patients with primary central nervous system lymphoma. Oncotarget. 2017;8(50):87317-28.

41. Sugita Y, Furuta T, Ohshima K, Komaki S, Miyoshi J, Morioka M, Abe H, Nozawa T, Fujii Y, Takahashi H, et al. The perivascular microenvironment in Epstein-Barr virus positive primary central nervous system lymphoma: the role of programmed cell death 1 and programmed cell death ligand 1 . Neuropathology. 2018;38(2):125-34

42. Hong JY, Ryu KJ, Lee JY, Park C, Ko YH, Kim WS, Kim SJ. Serum level of CXCL10 is associated with inflammatory prognostic biomarkers in patients with diffuse large B-cell lymphoma. Hematol Oncol. 2017;35(4):480-6.

43. Kim SJ, Ryu KJ, Hong M, Ko YH, Kim WS. The serum CXCL13 level is associated with the Glasgow prognostic score in extranodal NK/-cell lymphoma patients. J Hematol Oncol. 2015;8:49.

44. Yi JH, Ryu KJ, Ko YH, Kim WS, Kim SJ. Profiles of serum cytokines and their clinical implications in patients with peripheral T-cell lymphoma. Cytokine. 2019:113:371-9.

45. Durum SK, Candeias S, Nakajima H, Leonard WJ, Baird AM, Berg LJ, Muegge K. Interleukin 7 receptor control of T cell receptor gamma gene rearrangement: role of receptor-associated chains and locus accessibility. J Exp Med. 1998;188(12):2233-41.

46. Kinter AL, Godbout EJ, McNally JP, Sereti I, Roby GA, O'Shea MA, Fauci AS. The common gamma-chain cytokines IL-2, IL-7, IL-15, and IL-21 induce the expression of programmed death-1 and its ligands. J Immunol. 2008; 181(10):6738-46.

\section{Publisher's Note}

Springer Nature remains neutral with regard to jurisdictional claims in published maps and institutional affiliations.

Ready to submit your research? Choose BMC and benefit from:

- fast, convenient online submission

- thorough peer review by experienced researchers in your field

- rapid publication on acceptance

- support for research data, including large and complex data types

- gold Open Access which fosters wider collaboration and increased citations

- maximum visibility for your research: over $100 \mathrm{M}$ website views per year

At $\mathrm{BMC}$, research is always in progress.

Learn more biomedcentral.com/submissions 